typer tilknytningsatferd utløses hos det syke eller sykdomstruede menneske, hos omsorgsgivere og andre nære pårørende og hos hjelperne i helsevesenet.

I de første kapitlene får vi en gjennomgang av begreper som «sykdom», «symptomer» og «lidelse». Vi føres inn i begreper som det engelske språket er så mye rikere på enn vårt eget: «illness», «sickness», «disease» og «disorder», nyanser som alle som arbeider med «sykdom» bør ha et reflektert forhold til.

I kapittel 2 og kapittel 3 gis en grundig innføring i den nevrobiologiske basis for hjernens utvikling, sett lys av kunnskaper om genetikk, nevrobiologi og anatomi og hjernens vekst og utvikling. Wilkinson er innom et bredt felt av ny viten om hukommelse og læring, temperamentsfaktorer og emosjonell og sosial utvikling. Han vender hele tiden tilbake til tilknytningsteorien som det bærende element i sin modell, en modell han har utviklet i samarbeid med Pat Crittenden.

Videre går Wilkinson i tre nye kapitler gjennom sykdomsspråket og det han mener er typisk atferd hos mennesker som gjør bruk av de ulike tilknytningsstrategiene den balanserte, trygge (type B), den forbeholdne (type A) og den «selvopptatte» (type C). Modellen brukes til å vise hvordan tilknytningsmønsteret får konsekvenser for sykdomsspråket. Tilknytningsatferden (på godt og vondt) preger oppfatningen av sykdommen og relasjonen til de tilgjengelige hjelperne. Konstruktive, men også destruktive mestringsstrategier tas i bruk. I teksten utviskes forskjellene mellom «psykiatrisk» og «somatisk» helsevesen. Tilknytningsstrategiene er i bruk både «på kirurgen»

og «på psykiatrisk» (og slett ikke bare hos fastlegen).

Vår rolle som hjelpere reflekteres også. Vi har alle våre tilknytningsmønstre som spiller seg ut i disse møtene. De siste kapitlene er viet nettopp dette, først i forhold til de «tvetydige symptomene» og betydningen av vår holdning og rolle. Pasienten trenger å bli møtt av en lege med en atferd som «tunes inn» i forhold til hennes mønster. Det handler blant annet om å finne balansen mellom følelser og rasjonale i et «måljustert felleskap».

Med henvisning til Bowlby mener forfatteren at «vellykket behandling, uansett om det dreier seg om psykiatri eller indremedisin, er avhengig av at pasienten har en trygg nok base». «Cure» og «care» henger tett sammen. Gjennom tilknytningsteori tilbyr Wilkinson oss en måte å forstå forbindelsen på. Gjennom å bli oss mer bevisst våre egne tilknytningsmønstre kan vi hjelpe pasientene bedre. Det er et verktøy for å redusere dysfunksjonelle samhandlingsmønstre i lege-pasient-forholdet.

Dette er en tekst som krever sin leser. Den er spekket med informasjon. Her er henvisninger til ulike forståelsesmodeller, som underbygges med referanser. Referanseliste og stikkordliste er tilgjengelig for den som vil trenge videre inn i stoffet. Figurer og bokser med tabeller og oversikter hjelper leseren underveis. «Ida» og beskrivelsene av hennes vei gjennom forskjellige utviklingsstadier er til hjelp for leseren når det gjelder å forstå og følge resonnementet. Dessverre er boken preget av et nokså tungt språk med lange setninger. Grundigheten går en del steder på bekostning av tilgjengeligheten.

Likevel: Jeg anbefaler Lidelse og lindring til alle som ønsker en teoretisk tilnærming til temaet. Hold ut gjennom et litt tungt akademisk språk til siste kapittel. Der kommer det praktiske råd og kloke leveregler! Et «måljustert fellesskap for helse» kan pasientene og vi jammen trenge. Wilkinson trekker opp en viktig vei for pasientbehandler-relasjonene i vårt moderne helsevesen, som er preget av teknologiske nyvinninger og stort pengeforbruk på den ene side og av forventningskrise på den annen.

\section{Ida Garløv}

Barne- og ungdomspsykiatrisk avdeling

Stavanger universitetssykehus

\section{Narkotikadebatt i svensk perspektiv}

Johansson E, Laanemets L, Svensson K, red. Narkotikamissbruk

Debatt, behandling och begrepp. $186 \mathrm{~s}$. Lund: Studentlitteratur, 2009. Pris SEK 223 ISBN 978-91-44-05212-0

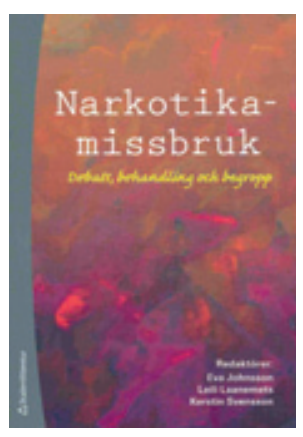

Økningen i bruken av illegale rusmidler er et betydelig sosialt og helsemessig problem i de fleste land. Debatten har ofte vært intensiv, ikke minst i Sverige. Dette er en artikkelsamling som sikter mot

å belyse og avklare prinsipper og sentrale begreper. Det er ett kapittel om viktige aktører i utviklingen av svensk narkotikapolitikk, ett om misbruksutvikling som karriere, ett om narrativ forståelse av misbrukende kvinner, ett om språk og sjargong i rusmiljøene, ett om motivasjonsarbeid og ett om tilbakefall og tilbakefallsforebygging. Kapitlet Att knarka eller inte knarka belyser misbruk i et sosiokulturelt perspektiv og kontrollproblemene i legemiddelassistert rehabilitering (LAR) på grunnlag av empirisk forskning. Avslutningskapitlet binder sammen en del av temaene ut fra en forståelse av misbruk som sosialt problem og sosialt arbeid som problemløsning.

Forfatterne av de ulike kapitlene er lærere og forskere ved svenske universiteter og høyskoler med sosiale utdanninger. Boken preges noe av at bidragene er innspill i en debatt som norske lesere ikke nødvendigvis kjenner seg igjen i, men de fleste kapitlene er dyptpløyende og gir gode analyser av sentrale spørsmål. Narkotikamissbruk kan derfor være interessant for dem som er opptatt av utviklingen i svensk narkotikapolitikk og svenske retningslinjer. Den kan også være interessant for dem som ønsker å trenge inn i en sosial forståelse av misbruksutvikling og få nyansert innsikt i muligheter og begrensninger ved sosialt arbeid.

\section{Helge Waal}

Senter for rus og avhengighetsforskning (SERAF) Institutt for psykiatri

Universitetet i Oslo

\section{Ikke så tilfeldig likevel?}

\section{Stams $\varnothing$ MA, red Velferdsstaten i endring}

Norsk sosialpolitikk ved starten av et nytt århundre. 2. utg. 354 s, tab, ill. Oslo: Gyldendal Akademisk, 2009. Pris NOK 450 ISBN 978-82-05-39360-8

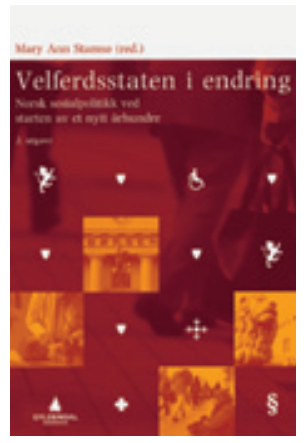

Dette er annenutgaven av en lærebok i helseog sosialpolitikk for studenter. Den består av 12 selvstendige kapitler av seks forfattere som til sammen dekker et tverrfaglig spekter fra sosialmedisin via sosiologi til sam-

funnsøkonomi. Alle kapitlene er skåret over samme pedagogiske lest. De avrundes med et oppsummeringsavsnitt, oppgaver til diskusjon og litteraturliste.

Dette er ikke noe man leser fra perm til perm for fornøyelsens skyld. Men det går an å slå opp. Via kapitteloverskrifter og et ryddig stikkordregister finner man omtaler av de aller fleste av velferdsstatens lover, institusjoner og begreper. Teksten dekker med andre ord mange temaer, den blir til gjengjeld mye preget av oppramsing på bekostning av dybde.

Siden man har fått med så mye, burde også forholdet mellom sosialpolitikken og arbeidsmarkedet vært behandlet. Den generelle betydningen av arbeidervernlovgiving er for eksempel glemt, selv om arbeiderkommisjonen av 1885 er omtalt. I motset- 
ning til mange andre europeiske land har Norge beholdt det meste av arbeidervernet trass i alle OECD-råd om å «fleksibilisere» arbeidslivet. Hva forteller det om den norske velferdsstaten?

Undertegnede synes teksten er for lite utfordrende for studenter, den blir simpelthen for kjedelig. Jeg tror ikke forfatterne er uvitende om at det står strid om sosialpolitikken, men de holder tett om det. I et interessant kapittel om teorier om sosiale problemer definerer en av dem (Hjelmtveit) «sosialt problem» i sosialpolitisk sammenheng. Han knytter definisjonen til krav om forandring: «Om det settes i verk tiltak, og hva tiltakene eventuelt består i, vil avhenge av hvilke grupper som har nok makt til å sette situasjonen på dagsorden, til å få allmenn aksept for sin definisjon av problemet, og til å få gjennomført aktuelle tiltak» (s. 121). Men selv om det i resten av boken beskrives mange tiltak mot sosiale problemer, får vi ikke høre mer om hvilke grupper som har definert problemene og ønsket tiltakene. Utviklingen fremstår som en tilfeldig veksling i ideenes verden mellom trosretninger - høyreliberalisme, markedsøkonomi og sosialdemokrati. Moderne reformer presenteres med de samme formålene som de ble lansert med av ministrenes kommunikasjonsrådgivere. Jeg vet ikke om det er forlaget eller forfatterne som mener at en akademisk lærebok må beskrive velferdsstaten som om den var høyt hevet over gruppeinteresser. Uansett går det utover studentene.

\section{Ebba Wergeland}

Arbeidstilsynet

Oslo

\section{Nyttig viten om kvinnelig omskjæring}

Berggren V, Franck M, red

Kvinnlig könsstympning

137 s, tab, ill. Lund: Studentlitteratur, 2008.

Pris SEK 197

ISBN 978-91-44-04672-3

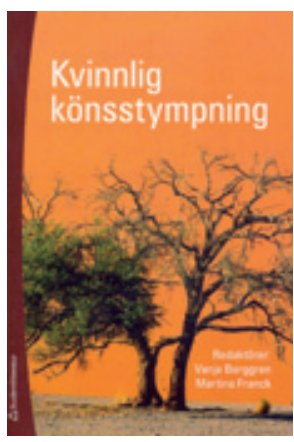

Denne utgivelsen er først og fremst beregnet på ansatte i helse- og sosialsektoren, men er også relevant for ansatte i skolen, barnevernet, politiet og dem som arbeider med flyktninger og asylsøkere. Studenter og forskere som er opptatt av temaet vil også ha glede av den.

Den kommer som paperback. Det er sju kapitler fra seks bidragsytere: sykepleier og folkehelseekspert Vanja Berggren, sosialantropolog Aud Talle, lege Lars Almroth, jordmor Owolabi Bjälkander, lege Birgitta Essen og jurist Pernilla Leviner. Språket er svensk. På forsiden er det bilde av to typisk afrikanske trær. Det ene er i ferd med å visne og kan symbolisere håpet om at kvinnelig omskjæring, en skikk som sett utenfra virker brutal og meningsløs, vil forsvinne.

Omskjæring av kvinner er en tabubelagt tradisjon som vekker sterke føleleser. Verdens helseorganisasjon anslår at 100-140 millioner nålevende jenter og kvinner har vært utsatt for dette. Noen av dem kommer i kontakt med helse- og sosialtjenestene og skolevesenet i Norge - som fødende, mødre eller eksperter. Hensikten med denne utgivelsen er å gi svar på følgende spørsmål: Hvordan kan vi bedre møtet med omskårne kvinner og utvide vår kompetanse på området? Hvilke ulike forklaringer finnes på at tradisjonen holdes i hevd? Hva sier lovgivningen? Det er en fyldig beskrivelse av historiske og kulturelle sammenhenger, og vi får god oversikt over forskjellige typer kvinnelig omskjæring og medisinske komplikasjoner. Det er også et kapittel om erfaringer fra helsevesenets møte med omskårne kvinner, med lærerike kasuistikker og nyttige kliniske råd.

Det juridiske aspektet er behandlet i et eget kapittel. I forhold til målgruppen kan det virke som om dette er for omfattende og preget av unødvendig teoretisk detaljrikdom. Dette gjør at teksten til tider er vanskelig å lese og at hovedbudskapet blir utydelig. De fleste omskårne kvinner i Skandinavia er flyktninger. Deler av kapitlet om juridiske forhold kunne vært erstattet med et kapittel om flyktningers spesielle medisinske og psykososiale behov.

Totalt sett gir Kvinnlig könnsstympning en allsidig innføring i kulturelle, medisinske og juridiske aspekter ved kvinnelig omskjæring. I tidligere litteratur rettet man oppmerksomheten mot medisinske aspekter på den ene side og kulturelle på den annen. Her gjør den brede tilnærmingen med nordisk fokus både fra medisinsk, kulturelt og juridisk ståsted denne utgivelsen enestående i sitt slag. Dette er nyttig lesning for alle som har behov for å utvide sine kunnskaper om dette kompliserte temaet. Med en bredere forståelse står vi bedre rustet til å ta de riktige skrittene i forbyggende arbeid og for å bygge opp et godt helsetilbud til de berørte.

\section{Siri Vangen}

Nasjonalt kompetansesenter for kvinnehelse Kvinneklinikken

Oslo universitetssykehus, Rikshospitalet

\section{Nettbasert utdanning - kort og godt}

Hrastinski S.

Nätbaserad utbildning

En introduktion. $144 \mathrm{~s}$, tab, ill. Lund:

Studentlitteratur, 2009. Pris SEK 280

ISBN 978-91-44-05324-0

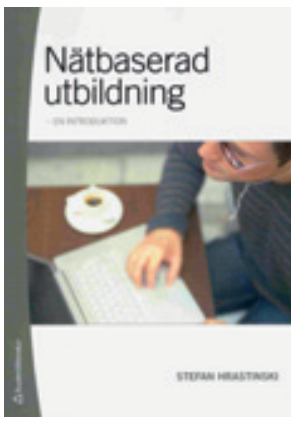

Nettbaserte teknikker benyttes i dag som støtte for nesten all utdanning og kursvirksomhet. Hrastinski har skrevet en enkel, forskningsbasert populærinnføring for alle som vil vite mer om hvordan man best gjør seg nytte av nettbaserte teknikker i undervisningen.

Nettbasert utdanning omfatter langt mer enn rendyrket fjernundervisning på Internett. Studentene lærer av hverandre ved å lese blogger og delta i diskusjonsfora eller ganske enkelt ved å utveksle undervisningsmateriell via e-post. Fremveksten av sosiale medier som Facebook og YouTube har ifølge Hrastinski bidratt til et paradigmeskifte innen utdanning. Læreren skal ikke lenger utelukkende formidle kunnskap, men, som det står i etterordet, være «facilitator», den som organiserer læringen og ser til at gruppen når sitt fulle kunnskapspotensial gjennom interaksjon med hverandre og omgivelsene. Den som ikke hiver seg på utviklingen og evner å forstå hva wiki, blogg, podcast, chat og web 2.0 dreier seg om, vil snart føle seg hjelpeløs.

Denne utgivelsen er primært beregnet på lærere, forskere og studenter, men kan leses av alle som vil gjøre bruk av nettbaserte teknikker i undervisningen. Språket er godt og teksten lettlest. Kapitlene er pedagogisk oppbygd med ingress, underoverskrifter, oppsummering og refleksjonsspørsmål. Figurene er enkle, men illustrative, og tabellene tjener sitt formål. De fem første kapitlene gir et historisk overblikk over nettbasert utdanning, diskuterer nettutdanning i en pedagogisk kontekst, presenterer ulike nettbaserte teknikker og dveler ved kommunikasjon og ulike typer av læringsfellesskap og samarbeidsformer på nettet. I det sjette kapitlet redegjør Hrastinski for sin egen videreutviklede modell om uformell versus formell interaksjon mellom studenter. Han argumenterer for å legge til rette for uformell interaksjon ved for eksempel chatting og diskusjonsfora for å fremme læringsfellesskapet og øke læringsutbyttet. I det sjuende og siste kapitlet oppsummerer han hvilke faktorer som påvirker hvordan man lykkes med nettbasert utdanning. Gjennom det hele lar 